\title{
The effect of realistic mathematical approaches towards the students' math learning outcomes
}

\author{
Qomario Qomario *, Ahmad Tohir, Ali Mashari \\ Department of Primary Education, STKIP Al Islam Tunas Bangsa. \\ Jalan ZA PagarAlam No. 41, Gedungmeneng, Bandar Lampung35145, Indonesia \\ * Corresponding Author. E-mail: qomario@ stkipalitb.ac.id
}

Received: 19 June 2020; Revised: 20 June 2020; Accepted: 23 June 2020

\begin{abstract}
This research aimed to describe the effect of realistic mathematical approaches on mathematics learning outcomes of fourth grade students at SDN 4 Jatimulyo. Type of this research is quantitative research using quasi-experimental methods and using one-group pre-test and post-test design. This research is conducted for grade IV odd semester 2019/2020 at SDN 4 Jatimulyo. The population in this research are all fourthgrade students of SDN 4 Jatimulyo with a total of 31 students. The sampling using saturated sampling technique (total sampling), thus the sample in this research amounted to 31 students. The data collection is done through tests, namely pre-test and post-test. The data analysis technique used in this study is descriptive analysis. Based on the result and discussion in this research, it can be concluded that there is an effect of a realistic mathematical approach to the mathematics learning outcomes of fourth grade students at SD N 4 Jatimulyo. This is evidenced by the mean value of mathematics learning outcomes is 83.84 (very good category). From these results it can be concluded that there was an effect of a realistic mathematical approach to student mathematics learning outcomes.
\end{abstract}

Keywords: learning outcomes, realistic mathematical approach.

How to Cite: Qomario, Q., Tohir, A., \& Mashari, A. (2020). The effect of realistic mathematical approaches towards the students' math learning outcomes. Jurnal Prima Edukasia, 8(1), 78-85. doi:https://doi.org/10.21831/jpe.v8i1.32577

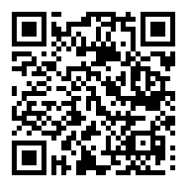

\section{Introduction}

Education is about how to improve students' learning outcomes. This case will continue in order to the future generations can grow and have competitiveness. Education is one of the important things and plays a role in human life. Education teaches humans to know and utilize the resources to their full potential so as able to survive. Education is a conscious and planned effort to actualize the learning process actively in order that students can develop their potential. The purpose of education based on Pancasila has the aim to increase piety towards God, intelligence, skills, enhance character, strengthen personalities thus they can build themselves and be jointly responsible for the national development (Tohir \& Mashari, 2020).

Mathematics is a subject containing full of life needs, such as a means of education. Mathematics as a means of education plays a role in human activities obtained from the thinking process, and it was not obtain from the experimental results (Damayanti \& Mawardi, 2018). The learning and teaching of mathematics can be analyzed from different psychological points of view. Information-processing theories focus on the various information-processing mechanisms underlying mathematical competence and try to foster the development of these mechanisms in order to stimulate the growth of mathematical competence. In the action-psychological approach of the cultural-historical school, mathematics is viewed as a kind of culturally developed human activity governed by the rules that mathematicians themselves follow while doing their job. Consequently, the development of mathematical competence is regarded as the formation of a system of meaningful mathematical actions that constitute that activity. At a general theoretical level these approaches can be shown to be basically different and even incompatible. With regard to mathematics education the differences are illustrated with respect to several themes such as task-analysis, automatization, and the learning of elementary arithmetic. Considering insight and meaningful and sophisticated problem-solving as the core of mathematical thinking, the action- 
psychological approach appears to be the more promising candidate as an aid in the design of future mathematics education (Oers, 1990).

In this modern era, the learning process that is applied tends to use the constructivism approach, taken from the word "construction" which means to build. The theory of constructivism realizes that knowledge cannot be transferred just like that, but rather must be interpreted by each individual. Knowledge is also a process that develops continuously. For this reason, a person's activeness is crucial in developing knowledge (Cahyo, 2013).

Jean Piaget who is the most prominent cognitive psychologist and also known as the first constructivist asserted that the emphasis of the theory of constructivism lies on the process of finding theories or knowledge that are built from field reality (Cahyo, 2013). For this reason, it can be concluded that good knowledge is built from events, concrete experiences or phenomena. But in reality, education in Indonesia still tends to transfer the knowledge possessed by teachers to their students, especially in learning mathematics. As a result, students do not understand how the knowledge is built and when the knowledge learned can be used to solve problems that they find in their daily life so that the knowledge loses meaningfulness (Fitra, 2018).

Mathematics is unconsciously related directly to one's daily activities and is often used for solving the problems. Besides that, mathematics is the science of logical reasoning and problems related to numbers. The abstract nature of mathematical objects causes many students to have difficulty in understanding mathematical concepts. As a result, students' mathematical achievements in general have not been encouraging. The abstract mathematical concept is something that is considered easy for adults, but is considered difficult to understand for a child. Elementary school children still think at the stage of concrete operations and to arouse interest in learning mathematics, the teacher must be creative in conducting and creating learning situations (Farida, 2018).

Teaching mathematics in elementary school is generally still conventional, namely lectures, questions and answers, and assignments. Besides the application of mathematics learning methods are still teacher oriented, therefore students tend to be passive. Teachers in conventional learning usually put more emphasis on using formulas and giving exercises, thus students are only accustomed to do the exercises without being trained to think and understand the concepts. Feeling sleepy, playing alone, do not want to do the exercises, and even fighting while learning is a result of the lack of students' active contribution in the learning process. If this case already happened, then there is no improvement in mathematics learning activities and student learning outcomes are not as expected (Lazuardi et al., 2017).

The results of observations and interviews at SD N 4 Jatimulyo obtained data that mathematics is a subject that is considered difficult by students. It is also based on students' learning outcomes on fraction material, from 31 students, there are 11 students (35.48\%) scored above the Minimum Mastery Criteria (KKM) that has been set ie 65, while 20 students $(64.52 \%)$ scores under the KKM.

To overcome these problems, it is necessary to make improvements in learning so as to create a pleasant learning atmosphere, learning activities occur, and provide opportunities for students to rediscover mathematical ideas and concepts in their own way under the guidance of the teacher. One learning that can be an alternative in order to create fun learning, encourage student activity, and the discovery of mathematical ideas or concepts is realistic mathematics learning.

Realistic Mathematics Learning (PMR) is used because this approach is a learning approach that directs students to learning meaningfully, according to students 'thinking abilities and is related to students' daily lives. This connects to their daily life that will direct students to the understanding that Mathematics is not only symbolic science but can be utilized in daily life to help and facilitate human work in solving life's problems. Provision of meaningful Mathematics learning to students and do not separate learning Mathematics with the experience of students' daily life, students will be able to apply Mathematics in life and not forget it quickly (Artawan et al., 2014).

The main idea of a realistic mathematical approach is that students must be given the opportunity to rediscover mathematical ideas and concepts with adult guidance through exploring various real-world situations and problems (Usdiana, 2009). PMR learning begins with the presentation of contextual problems. Presentation of contextual issues is very important (Gumanambo et al., 2016). This is in line with Pitadjeng (2005) stating that students can learn mathematics in a pleasant atmosphere that the teacher must strive for pleasant situations and conditions, linking students' real-life experiences with mathematical ideas in learning. 
The research that was conducted by Marta (2018) states that the application of the PMR approach can improve mathematics learning outcomes of third grade students at SD Negeri 018 Langgini. In addition, research that was conducted by Fachrurazi (2017)states that mathematics learning with the PMR Approach of food package presentation models on FPB and KPK material is very suitable to be applied in the process of learning mathematics in elementary schools. The purpose of this research is to describe the effect of a realistic mathematical approach to the mathematics learning outcomes of fourth grade students at SDN 4 Jatimulyo.

\section{Method}

Type of this research is quantitative research using quasi-experimental methods and using onegroup pre-test and post-test design (Sugiyono, 2014). This research is conducted for grade IV odd semester 2019/2020 at SDN 4 Jatimulyo, Lampung.

The population in this research are all fourth-grade students of SDN 4 Jatimulyo with a total of 31 students. The sampling using saturated sampling technique (total sampling), thus the sample in this research amounted to 31 students.

The data collection is done through tests, namely pre-test and post-test. The data analysis technique used in this study is descriptive analysis. according to Sugiyono (2014), descriptive analysis is a statistic used to analyze data by describing or describing data that has been collected as it is without intending to make conclusions that apply to the public or generalizations. After the learning outcomes data is collected, the calculation results are converted based on the Table 1 (Arikunto, 2010):

Table 1. Rating Categories

\begin{tabular}{ccc}
\hline No. & Level of Mastery & Category \\
\hline 1. & $82-100$ & Very Good \\
2. & $71-81$ & Good \\
3. & $60-70$ & Enough \\
4. & $49-59$ & Less \\
5. & $<40$ & Very Poor \\
\hline
\end{tabular}

\section{Result and Discussion}

The quality of education that teachers provide to student is highly dependent upon what teachers do in the classroom. Thus, in preparing the students of today to become successful individuals of tomorrow, science and mathematics teachers need to ensure that their teaching is effective. Teachers should have the knowledge of how students learn science and mathematics and how best to teach. Changing the way we teach and what we teach in science and mathematics is a continuing professional concern. Efforts should be taken now to direct the presentation of science and mathematics lessons away from the traditional methods to a more student-centered approach. In an era dominated by mathematics, science, and technology, it is essential that science and mathematics be taught in K-12 and that classroom teachers are equipped with the knowledge and skills to teach both science and mathematics meaningfully to students. However, in a test driven curriculum where students and teachers are evaluated on student performance based on reading and mathematics standardized test scores, teaching meaningful science remains a challenge (Furner \& Kumar, 2007).

This research aimed to describe the effect of realistic mathematical approaches on students' mathematics learning outcomes. In this research, a pre-test was conducted to find out the extent of the students' initial concepts and after the post-test. Pre-test and post-test were used to find out whether realistic mathematical approaches affect the mathematics learning outcomes of Grade IV SDN Jatimulyo students. The average of pre-test and post-test values can be seen in Table 2.

Table 2. The average values of Pre-test and Post-test

\begin{tabular}{cccc}
\hline No. & Total of Students & The average values of pre-test & The average values of post-test \\
\hline 1. & 31 & 51,77 & 83,84 \\
\hline
\end{tabular}

Based on the Table 2, it can be seen that the average values of pre-test was 51.77 and the average values of post-test was 83.84. For more complete information about student mathematics learning outcomes (post-test) can be seen in the following descriptive statistical analysis table (Table 3 ). 
Jurnal Prima Edukasia, 8 (1), 2020 - 81

Qomario Qomario, Ahmad Tohir, Ali Mashari

Table 3. Descriptive Statistical Analysis

\begin{tabular}{cccccccc}
\hline No. & $\begin{array}{c}\text { Total of } \\
\text { Students }\end{array}$ & Minimum & Maksimum & Mean & $\begin{array}{c}\text { Std. } \\
\text { Deviation }\end{array}$ & $\begin{array}{c}\text { Skewness } \\
\text { Statistic }\end{array}$ & $\begin{array}{c}\text { Kurtosis } \\
\text { Statistic }\end{array}$ \\
\hline 1. & 31 & 65 & 100 & 83,84 & 9.501 & .074 & -.906 \\
\hline
\end{tabular}

Skewness and kurtosis are measures to see whether the data on mathematical values are normally distributed or not. Data is said to be normally distributed if the value of skewness and kurtosis is close to 0 . Based on the data above, the value of skewness and kurtosis is 0.074 and -0.906 so it can be concluded that the data of mathematical values are normally distributed. Furthermore, the mean value of mathematics learning outcomes is 83.84 . Based on Table 1 data, the value of 83.84 belongs to the very good category. this shows that learning using a realistic mathematical approach influences student learning outcomes with very good categories.

In accordance with the results of the research, a realistic mathematical approach was successful as an alternative learning approach to mathematics. One of the fundamental characteristics in RME was introduced by Frudenthal is guided reinvention as a process by which students actively seek to rediscover a mathematical concept with teacher guidance. Mathematics is a process to mathematicize a phenomenon. In the application of RME, there are two types of mathematical, namely horizontal mathematical and vertical mathematical. Horizontal mathematically is related to the generalization process which begins with the identification of mathematical concepts based on regularities and relationships that are discovered through visualization and schematization of the problem. Therefore, in this horizontal mathematical study students try to solve problems from the real world, using their own language and symbols, and still depend on the model. In contrast to vertical mathematically which is a form of the formalization process (formalizing) where the mathematical model obtained in horizontal mathematically becomes the foundation in the development of more formal mathematical concepts through a vertical mathematical process. In other words, these two types of mathematically cannot be separated sequentially, but both occur alternately and gradually. Thus, in RME realistic problems are used as the main stimulator in the effort to reconstruct students' knowledge. In addition, the application of RME is accompanied by the use of models so that learning is truly imaginable for students, therefore $t$ it refers to solve the problems with various alternatives through mathematical processes that is carried out by students themselves (Wijaya, 2012).

The success of the mathematical approach in improving mathematics learning outcomes cannot be separated from the advantages of the realistic mathematical approach itself. According to Sam (Sumianto, 2018), several advantages of realistic mathematical approaches in learning include; (a) because students build their own knowledge, students do not easily forget their knowledge. (b). the atmosphere in the learning process is fun because it uses the reality of life, so students will not be bored quickly to learn mathematics. (c). Students feel valued and are more open because each student's answer has a value. (d). Foster teamwork. (e). Practice the courage of students because they have to explain the answer. (f). Train students to have critical thinking and expressing opinions. (g). Ethical education, for example: mutual cooperation and respect for friends who are talking.

One philosophy that underlies a realistic approach is that mathematics is not a complete set of rules or traits that students must learn. According to Freudenthal (1991) that mathematics is not a subject that is ready for students, but a dynamic lesson that can be learned by working on it. Mathematical learning in the constructivist view is to provide opportunities for students to construct the mathematical concepts / principles with their own abilities through the process of internalization. The teacher in this case acts as a facilitator. According to Davis (1996), constructivist views in mathematics learning are oriented to: (1) knowledge is built in the mind through the process of assimilation or accommodation, (2) in the process of mathematics, every step a student is confronted with, (3) new information must be related to his experience about the world through a logical framework that transforms, organizes, and interprets their experiences, and (4) the center of learning is how students think, not what they say or write. This constructivist was criticized by Vygotsky, who stated that students in constructing a concept need to pay attention to the social environment. This constructivism is called by Vygotsky social constructivism (Taylor, 1993). Scaffolding is giving a number of assistance to students during the initial stages of learning, then reducing assistance and providing opportunities to take over greater responsibilities after he can do it (Slavin, 1997). Scaffolding is a help given to students to learn and solve problems. The assistance can be in the form of instructions, encouragement, and warnings, describe the 
Jurnal Prima Edukasia, 8 (1), 2020 - 82

Qomario Qomario, Ahmad Tohir, Ali Mashari

problem in the steps of solving, providing examples, and other actions that enable students to learn independently. The approach refers to social constructivism (social constructivist philosophy) is called the social constructivist approach. Social constructivist philosophy views mathematical truth as not absolute and identifies mathematics as the result of problem solving and problem posing by humans (Ernest, 1991). In learning mathematics, Cobb, et. al (1992) called it as socio-constructivism (socioconstructivism). Students interact with the teacher, with other students and based on informal experiencees students develop strategies to respond to the problems given. The characteristics of this socio constructivist approach are very much in accordance with the characteristics of the RME (Mustamin, 2017).

In RME, context problems are intended for supporting a reinvention process that enables students to come to grips with formal mathematics. This approach is primarily described from an instructionaldesign perspective. The instructional designer tries to construe a route by which the conventional mathematics can be reinvented. Such a reinvention route will be paved with context problems that offer the students opportunities for progressive mathematizing. Context problems are defined as problems of which the problem situation is experientially real to the student. An RME design for a calculus course is taken as an example, to illustrate that the theory based on the design heuristic using context problems and modeling, which was developed for primary school mathematics, also fits an advanced topic such as calculus. Special attention is given to the RME heuristic that refer to the role models can play in a shift from a model of situated activity to a model for mathematical reasoning. In light of this modelof/model-for shift, it is argued that discrete functions and their graphs play a key role as an intermediary between the context problems that have to be solved and the formal calculus that is developed (Gravemeijer \& Doorman, 1999). Many teachers still use traditional methods in teaching mathematics concept which by several studies have been proven not efficient. Teaching reformation in the mathematics classroom in needed and there is the theory of RME that will not only help the students learn but also help the teachers to demonstrate the importance of mathematics for daily life. The use of balancing concept in teaching the concept of equality in subject-centered approach is aligning the principles of the theory of RME and also helps create the learning atmosphere that is effective and efficient for both teachers and students. The three principles of the RME theory is very suitable for the teaching of mathematical concepts without forcing students to memorize. However teachers have to be critical in implementing the theory related to the value contained in it in delivering the lesson. Students are not the just a subject of the nature/environment. Students are the image of God who are given the ability to see God's truth and beauty through learning mathematics. This literature review has provided the expositions of how RME theory can be beneficial in teaching the concept of equality. However, the researcher is fully aware that the teaching using this theory can be time-consuming. Therefore this paper suggests to teachers who are willing to teach using the RME theory to precisely learn the arrange the lesson plans, and be wise in determining the topics that need more concern. This paper also suggest teachers to be careful in designing the activities/realistic situations in order to create a maximum result of progressive mathematization according to the three principles of RME theory (Theodora \& Hidayat, 2018).

RME bring students to the real world of everyday experience, so that lessons learned in the mathematics classroom is not separate from everyday life of students. The use of real world helps improve students' understanding of mathematical concepts that are abstract. The lessons involve everyday experiences of students and existing culture. This make learning more meaningful for students. The realistic mathematics education approach will help students understand concept and use these concepts in solving mathematics problems at a higher level. Quality of teaching is very dependent on what teachers do in the classroom. By using Realistic Mathematics approach students are more active during the process of teaching and learning, the teacher act only as a facilitator for them (Zakaria \& Syamaun, 2017).

Students who had a good understanding of the concepts connected to the achievement. This study also supported Muzakkir (2010) and Sumitro (2008) showing that use of RME influenced mathematics achievement. Conceptual understanding of linear programming of experiment groups was higher than control groups in which one factor that can be identified was processes of teaching and learning. Horizontal matematization processes in RME provided opportunities for students to reflect pre-experience and pre-knowledge with various ways. Vertical matematization process provided opportunities for students to make their own statement based on development of model that they confirmed before formal 
knowledge. It was an important in RME to develop concept through contextual problem and to apply concept in real problem. Throughout worksheet of RME, students were able to solve realistic problems well and give full explanation about them. The study supported study Searle and Barmby (2012) who stated that students taught by RME had a higher ability to solve problem than students taught by traditional approach. They showed more complete and correct answer according to context question and had more different answer than students by traditional approaches. RME prioritized development of concept through a variety of environments and supported pre-knowledge so that students familiarized with different answers. Afri, et al. (2011) found that students' problem-solving skill with applying RME was better than traditional learning. In RME students were always involved with problem solving. Contextual problem solving was used as development of conceptual understanding and application in real condition. Contextual problem solving in RME also provided simple troubleshooting through several models. The presented models were not only focused on contextual problem solving but also helped students to view the relationship between some prior knowledge, environment and experience. Conceptual Understanding would be a strong conceptual understanding when students learn through "doing mathematics". Students should be active to construct their own knowledge through interaction with other people and environment. RME gave priority to develop conceptual understanding through "doing mathematics". Therefore, RME gave various examples with environment or experience or knowledge (Hidayat \& Iksan, 2015).

The result of this research that is relevant to this research including the research was conducted by Catrining \& Widana (2018) which shows that (1) there are differences between mathematics learning interests of students who follow the Realistic Mathematics Education (RME) learning approach and students who follow conventional learning approaches in grade VII students of SMP Negeri 6 Denpasar in the academic year 2017/2018, (2) there are differences between mathematics learning outcomes of students who take the Realistic Mathematics Education (RME) learning approach and students who follow conventional learning approaches in class VII students of SMP Negeri 6 Denpasar in the academic year 2017/2018, and (3) there were simultaneous differences between learning interest and mathematics learning outcomes of students who took the Realistic Mathematics Education (RME) learning approach and students who follow the conventional learning approach in class V students II SMP Negeri 6 Denpasar in the academic year 2017/2018. In addition, the research was conducted by Putra et al (2014) entitled "the effect of an origami-assisted realistic mathematics education approach to the learning outcomes of fifth grade elementary school mathematics students in the les village of Tejakula sub-district". Stating that the realistic mathematics education approach has a positive effect on the learning outcomes of students of grade $\mathrm{V}$ in elementary school in the village of Les.

In addition, the research was conducted by Wahyuni \& Jailani (2017) entitled "the effect of using realistic mathematics on motivation and learning achievement of primary school students". The result of the study shows that: (1) there is an effect of the realistic mathematics approach on the students' motivation at the significance level of $0.000<0.05$, (2) there is an effect of the realistic mathematics approach on the students' achievement at the significance level of $0.042<0.05$. The gain score of motivation and achievement in the control class are 0.0045 and 0.0897 , while the gain score of motivation and achievement in the experiment class are 0.745 and 0.434 . research was conducted by Ulandari et al (2019) entitled "development of learning materials based on realistic mathematics education approach to improve students' mathematical problem solving ability and self-efficacy". Based on the results of analysis and discussion in this study, it can be concluded that learning materials based on realistic mathematics education approach have met the effectiveness criteria, and mathematical problem solving ability and student self-efficacy have increased after using learning materials based on realistic mathematics education approach. This research shows that learning materials based on realistic mathematics education approach are important things to consider in an effort to maximize student mathematics learning achievement. Thus, it is expected that mathematics teachers seek mathematical learning using learning materials based on realistic mathematics education approach.

\section{Conclusion}

Based on the result and discussion in this research, it can be concluded that there is an effect of a realistic mathematical approach to the mathematics learning outcomes of fourth grade students at SD N 4 Jatimulyo. This is evidenced by the mean value of mathematics learning outcomes is 83.84 . (very good 
category). Therefore, the suggestions that can be concluded are: (1) for teacher, learning using a realistic mathematical approach can be implemented in the learning process as a variation of teaching so the learning will not be monotonous; (2) The realistic mathematics approach is proven to be able to improve student learning outcomes in order that the realistic mathematics approach is recommended to be continuously developed so that students are interested and motivated. Especially in teaching mathematics.

\section{References}

Arikunto, S. (2010). Prosedur penelitian suatu pendekatan praktek. Jakarta: Rineka Cipta.

Artawan, K. A., Japa, I. G. N., \& Suarjana, I. M. (2014). Penerapan pendekatan pendidikan matematika realistik indonesia untuk meningkatkan aktivitas dan hasil belajar matematika siswa kelas V SD. Jurnal Mimbar PGSD, 2(1).

Cahyo, A. N. (2013). Panduan aplikasi teori-teori belajar mengajar. Yogyakarta: Diva Press.

Catrining, L., \& Widana, I. W. (2018). Pengaruh pendekatan pembelajaran realistic mathematics education (RME) terhadap minat dan hasil belajar matematika. Emasains, 7(2), 120-129. https://doi.org/10.5281/ZENODO.2548071

Cobb, P., Yackel, E., \& Wood, T. (1992). A constructivist alternative to the representational view of mind in mathematics education. Journal for Research in Mathematics Education, 23(1), 2-33.

Damayanti, R., \& Mawardi, M. (2018). Developing of MITRA learning model of problem solving-based to solve mathematical problems in elementary school. Jurnal Prima Edukasia, 6(1). https://doi.org/10.21831/jpe.v6i1.17238

Davis, K. (1996). Human behavior at work: Organizational behavior (perilaku dalam organisasi) Terjamahan: Agus Dharma. Erlangga.

Ernest, P. (1991). The philosophy of mathematics education. London: The Falmer Press.

Fachrurazi, F. (2017). Pembelajaran matematika realistik di sekolah dasar pada materi FPB dan KPK dengan model penyajian paket makanan. Al-Khawarizmi: Jurnal Pendidikan Dan Pembelajaran Matematika, 1(2).

Farida, B. (2018). Penerapan pendekatan matematika realistik dalam peningkatan keaktifan dan hasil belajar matematika di kelas III Sekolah Dasar Negeri 4 Tanggung. Jurnal Ilmiah Pendidikan Dasar, 4(2), 81. https://doi.org/10.30659/pendas.4.2.81-90

Fitra, D. (2018). Penerapan pendidikan matematika realistik indonesia (PMRI) dalam pembelajaran matematika. JURNAL INOVASI EDUKASI, 1(1), 1-7. https://doi.org/10.35141/jie.v1i1.27

Freudenthal, H. (1991). Revisiting mathematics education. China Lectures Dordrecht: Kluwer.

Furner, J. M., \& Kumar, D. D. (2007). The Mathematics and science integration argument: A stand for teacher education. Eurasia Journal of Mathematics, Science \& Technology Education, 3(3), 5.

Gravemeijer, K., \& Doorman, M. (1999). Context problems in realistic mathematics education: A calculus course as an example. Educational Studies in Mathematics, 39(1/3), 111-129. https://doi.org/10.1023/A:1003749919816

Gumanambo, N., Sukayasa, S., \& Gandung, S. (2016). Penerapan pendekatan pembelajaran matematika realistik untuk meningkatkan hasil belajar siswa pada materi penjumlahan dan pengurangan bentuk aljabar di kelas VII SMPN 9 Palu. Jurnal Elektronik Pendidikan Matematika Tadulako, $4(1)$.

Hidayat, R., \& Iksan, Z. H. (2015). The effect of realistic mathematic education on students' conceptual understanding of linear progamming. Creative Education, 06(22), 2438-2445. https://doi.org/10.4236/ce.2015.622251

Lazuardi, M. A., Sugiarti, T., \& Agustiningsih. (2017). Penerapan pendekatan pembelajaran matematika realistik untuk meningkatkan aktivitas dan hasil belajar siswa pada materi trapesium dan layanglayang. Jurnal Edukasi, 4(3), 15-19. https://doi.org/10.19184/jukasi.v4i3.6149 
Marta, R. (2018). Penerapan pendekatan pembelajaran matematika realistik indonesia untuk meningkatkan hasil belajar matematika di SD Negeri 018 Langgini. Jurnal Cendekia: Jurnal Pendidikan Matematika, 2(1), 7-14. https://doi.org/10.31004/cendekia.v2i1.28

Mustamin, St. H. (2017). Pembelajaran matematika dengan pendekatan realistik. Lentera Pendidikan : Jurnal Ilmu Tarbiyah dan Keguruan, 20(2), 231-239. https://doi.org/10.24252/lp.2017v20n2i8

Oers, B. V. (1990). The development of mathematical thinking in school: a comparison of the actionpsychological and information-processing approaches. International Journal of Educational Research, 14(1). https://doi.org/10.1016/0883-0355(90)90016-2

Pitadjeng. (2005). Pembelajaran matematika yang menyenangkan. Semarang: Depdiknas Dirjen Dikti.

Slavin, R. E. (1997). Educational psychology theory and practice (Fifth Edition). Boston: Allyn and Bacon.

Sugiyono, S. (2014). Metode penelitian kunatitatif kualitatif dan R\&D. Bandung: Alfabeta.

Sumianto, S. (2018). Penerapan pendekatan matematika realistik (PMR) untuk meningkatkan hasil belajar matematika siswa kelas V Al-Azim SDIT Raudhatur Rahmah Pekanbaru. Jurnal Basicedu, 2(1), 49-56. https://doi.org/10.31004/basicedu.v2i1.26

Taylor, L. (1993). Vygotskian influence in mathematics education, with particular reference to attitude development. Spring \& Summer Edition Center For Teaching/Learning of Mathematics, $15(2 \&$ $3)$.

Theodora, F. R. N., \& Hidayat, D. (2018). The use of realistic mathematics education in teaching the concept of equality. JOHME: Journal of Holistic Mathematics Education, 1(2). https://doi.org/10.19166/johme.v1i2.913

Tohir, A., \& Mashari, A. (2020). Efektivitas model pembelajaran inkuiri dalam meningkatkan hasil belajar siswa kelas IV SDN 27 Tegineneng. Jurnal Ilmiah Sekolah Dasar, 4(1).

Ulandari, L., Amry, Z., \& Saragih, S. (2019). Development of learning materials based on realistic mathematics education approach to improve students' mathematical problem solving ability and self-efficacy. International Electronic Journal of Mathematics Education, 14(2). https://doi.org/10.29333/iejme/5721

Usdiana, D. (2009). Meningkatkan kemampuan berpikir logis siswa SMP melalui pembelajaran matematika realistik. Jurnal Pengajaran MIPA, 13(1).

Wahyuni, N. D., \& Jailani, J. (2017). Pengaruh pendekatan matematika realistik terhadap motivasi dan prestasi belajar siswa SD. Jurnal Prima Edukasia, 5(2). https://doi.org/10.21831/jpe.v5i2.7785

Wijaya, A. (2012). Pendidikan matematika realistik (suatu alternatif pendekatan pembelajaran matematika). Yogyakarta: Graha Ilmu.

Zakaria, E., \& Syamaun, M. (2017). The effect of realistic mathematics education approach on students' achievement and attitudes towards mathematics. Mathematics Education Trends and Research, 2017(1), 32-40. https://doi.org/10.5899/2017/metr-00093 